\title{
Santalum spicatum Oil
}

National Cancer Institute

\section{Source}

National Cancer Institute. Santalum spicatum Oil. NCI Thesaurus. Code C107366.

The oil extracted from the heartwood of Santalum spicatum. Australian sandalwood oil is used as a substitute for Inidan sandalwood oil in perfumery, aromatherapy and skin care. 